\title{
Development of E-Learning Management Model for Teaching System at The Police Academy
}

\author{
Elisa IkaYuniawati; Fakhruddin; Rusdarti; Kardoyo \\ Program Study Manajamen Pendidikan, Universitas Negeri Semarang \\ elisaika47@gmail.com
}

Article History: Received: 11 January 2021; Accepted: 27 February 2021; Published online: 5 April 2021

\begin{abstract}
This study aims to describe the development of e-learning management model for the teaching system at the Police Academy through management of educational information systems. The method used is research and development (R\&D). The development of e-learning management model for the teaching system as a research focus based on the Technology Accepted Model (TAM) theory and the education management information system input process output. The resulting model product is in accordance with the needs of police academy cadets in the use of e-learning. The product developed is an e-learning management system through an input output process. The results of a questionnaire to 100 Akpol cadets show that the e-learning management model of the teaching system is effective in providing convenience and information related to teaching at the Police Academy.
\end{abstract}

Keywords: e-Learning, education management information system, TAM, Indonesian Police Academy

\section{Introduction}

In the era of the industrial revolution 4.0, the technology, information and communication (ICT) is developing rapidly, which gradually shifted the use of conventional methods in education. This era disrupts human activities in which there is science and technology as well as higher education. Future educational challenges such as technological advances have entered in several fields, especially management in education information systems. Berge \& Huang (2004) revealed that a paradigm shift in learning systems such as traditional (conventional) learning to modern learning requires the formation of a new innovation to answer these challenges.

One of the information systems developed in the learning process online or through e-learning. In the learning process using e-learning which is integrated into an application that contains the education management information system. Implementation of the system requires good management involving all stakeholders to achieve quality education goals. Rosenberg (2001) states that increasing knowledge and performance can be done through the use of e-learning as one of the uses of internet technology.

. Rui-Hsin\& Lin's research (2017) found that the e-learning information system in the education and training of the Taiwan Police had a positive impact on the educational process, especially in its ease of use and quality of service through the fast web through the design and management of a good e-learning information system. An elearning information system should have several criteria such as ease of use, stakeholder support, and administrative officers. In his research, it was also revealed that the application of blended learning as a form of e-learning model in the information system can be used in the learning process to promote the learning independence of students and also increase the ability of human resources to operate educational information systems in police education and training.

Leal, J. (2009). The results of research conducted on training law enforcement officers in America found that the trend of using e-training and e-education systems through online learning portals can reduce the increase in costs of training through conventional means. In addition, through the application of technology in e-learning, it will produce trained employees according to the needs and demands of the future. The education system is needed in order to monitor the accountability, effectiveness and effectiveness of an education. Education management information systems that run well can support objective database decisions that can improve the quality of education through interactive and communicative information presentation. McMahon (2004) revealed that e-learning through this education management information system can be applied according to the needs and policies and educational issues that tend to change in the developing world..

Other e-learning models such as flipped classrooms can be used in the teaching process. The same thing was also said by Vioren et al (2019) who implemented flipped classrooms in medical education, which stated that the implementation of flipped classrooms could encourage student independence and be fully involved in learning where the material was uploaded through a video and the material was given online while face-to-face was used. to elaborate on the knowledge of the initial material read beforehand so that learners go through high-level learning.

E-Learning which is integrated into an education management information system can help the effectiveness of the teaching process. Kettunen, J., \&Kantola, I. (2005). The use of balance scored in a campus information management system strategy can combine all data into one information technology system through a web browser portal. Shah, M. (2014). The education management information system is effectively used in the 
governance of a school. Sagitova, G.K. (2012). Education management information systems in higher education institutions that are used correctly can determine the results of activities.

According to Fattah (2006) Education is a system that is seen both at the micro and macro level of education. Micro education is seen from the relationship of several elements, namely students, educators and their interaction in an educational effort. Micro education is seen through components consisting of a broad scope, namely input (input) - education process - education outcomes (output). A school organization as a system that contains input-process-output components. . This is in line with McMahon's (1993) definition, an education management information system contains data collected about the implementation of the education system that helps education administrators to monitor and improve education effectiveness. The process according to Khristianto, W., et all (2015) is an attempt to change or convert raw input into a format to make it meaningful. Through education management, the input process output through an easy-to-use information system in accordance with the concept of the technology acceptance model (TAM) by Davis (1989), provides a theory in studying and understanding user behavior towards technology.

The Police Academy is the only Academy in Indonesia that is tasked with producing future Polri leadership candidates. With the emergence of changes in the era of information disruption in the 4.0 revolution, it is a very big challenge for the Police Academy to carry out its role as an educational institution for prospective Police officers. One of the programs of the National Police Chief is to create a Promoter Polri, namely a professional, modern, and trusted Police. For this reason, the Police Academy must be able to produce output in accordance with the vision.

The implementation of education at the Police Academy in the teaching program uses several methods, namely through lectures, questions and answers, discussions, assignments, demonstrations, simulations, role playing, case studies, cooperative learning, collaborative learning, drill. In Article 14 of the Regulation of the Head of the National Police Education and Training Institute concerning obligations, one of which states that after participating in learning activities, Police Academy Cadets are required to learn lessons that are not followed by themselves and utilize technology to support tasks in accordance with applicable regulations. The use of e-learning is one of the technologies used in the Police Academy.

The development of an e-learning management model for the teaching system at the police academy can produce output that is in accordance with the vision and mission of the institution, but based on a preliminary study that has been carried out through a survey by researchers to teachers and cadets at the Police Academy, shows different things. Based on the survey, some information was obtained about the use of ICT at the Police Academy as a tool used in learning. In the use of the internet network by the teachers as respondents, it was found that as many as $79.4 \%$ of respondents used the internet network to find additional digital references that support the lecture process; $50 \%$ use the network for entertainment; $35.3 \%$ use e-learning sites; $11.8 \%$ gave online quizzes. In addition, respondents also very rarely open the Akpol e-learning site, both the Kendalisodo Police Academy management system and the Moodle platform found in the Police Academy Information System (SIAK). This is confirmed by the data that as many as $69.7 \%$ of respondents opened the application by only 25\%. In addition, the technology facilities in the Police Academy such as CBT, e-library, learning support information systems have never been used by $58.8 \%$ of respondents.

The lecture method is still a trend among the teachers. This can be obtained from the percentage of the lecture method used by the teacher, which is $>75 \%$ of the meetings using the lecture method. In giving assignments to cadets, as many as $61.8 \%$ of respondents were given assignments manually, namely doing assignments using folio sheets. $20.6 \%$ of their abilities and skills in using IT are limited, and $11.8 \%$ of respondents still have difficulty entering RPS content.

.Researchers are interested in carrying out this research because these problems are very important because: 1) to realize the application of e-learning 2) to achieve the vision and mission of the Police Academy to become education that produces professional, intelligent, moral, modern and global-minded police and international standards (World Class Police Academy) as well as organizing institutional management that is oriented to excellent service and develops into a center of excellence so that it can produce intelligent, moral, professional and modern Police Officers. 3) realizing cooperation and networking activities with several institutions both at home and abroad. Therefore, thorough improvement, consistency and awareness of all stakeholders must be made to achieve the Police Academy vision and mission. As for improvements that can be made through the model that will be developed, namely the Development of the e-learning Management Model for the Teaching System at the Police Academy.

\section{METHOD}

The Research and Development (R\&D) model was used in this study. R\&D is a research model used to design new procedures and products, systematically tested in the field, evaluated, and refined to meet certain criteria of effectiveness, quality, or the same standards (Borg and Gall, 2013). The stages in this research are 1) Preliminary stage: a) research and information gathering by conducting a literature review in order to obtain references on e-learning management; b) planning through preliminary research to explore the implementation of 
e-learning management in the existing Police Academy. 2) Development stage: a) conducting literature studies and needs analysis to explore data regarding the e-learning management model as expected by the Police Academy girl and cadet; b) initial product development: compiling the e-learning management model of the Police Academy; c) expert validation in order to obtain a revised model; d) main field trials by performing empirical validation; e) compile a hypothetical model of e-learning management model at the Police Academy. 3) Evaluation phase: a) conducting a limited trial to obtain input on the feasibility of the e-learning management model at the Police Academy; b) produce a final model of e-learning management at the Police Academy; c) test the effectiveness of the model.

\section{RESULTS \& DISCUSSION}

The use of ICT through e-learning to support teaching programs has been carried out since 2014 for the first time through the Police Academy information system (SIAK) using the Moodle web-based application used in the teaching process. Then right in October 2019, Akpol launched an Android-based Akpol information system with the name TIK Control Sodo. This application also contains features related to all teaching, training and care programs (jarlatsuh). Sodo control ICT is a transformation from SIAK which was originally only web-based and then simplified again. Both forms of e-learning applications are implemented limited to the launch of the application, but it is not yet at the stage of use in class

AKPOL e-learning is further developed through an Akpollearning management system application. In this application there is a limited menu which only contains schedules, teaching materials, and assignments. Of the three ICT utilization systems, of course, not all of them are running according to their objectives. The features available in the LMS at this time also do not fully address the needs of the teaching program. Based on the results of preliminary research on the model used, the management system used is limited and does not yet cover the entire e-learning management system through the input process output. The results of observations in the preliminary stage obtained the percentage of implementation of e-learning management using an education management system, the input process output, the amount of input is $24 \%$, the process is $12 \%$, and the output is only $1 \%$.

The input has not include RPS, regulations for the use of e-learning, data profiles for students and cadets, main and additional material through various formats. Likewise, the process only includes the implementation of limited teaching through web conferencing with less varied teaching methods where the delivery of material is limited through lectures, there is no interactive and innovative learning model that is integrated into the LMS at this time. There are no assignments and giving quizzes online by utilizing applications that On the Internet, the discussion feature is limited to sending via email mail. The output does not yet contain the results of the learning evaluation which can be downloaded and uploaded.

Based on the formulation of the preliminary research results, as a whole, it does not include all components in the input process output so that information according to user needs cannot be presented completely. In accordance with this research, a development model for e-learning management of teaching systems in Police Academy is designed using an education management information system assisted by an application that is used in the teaching process according to user needs. In this input system planning design contains how the initial planning of the completeness of supporting facilities and infrastructure for e-learning; an education management information system that contains information needed by cadets and all supporting stakeholders; digital training for teachers; designing learning documents such as curriculum, RPS, handbook which are connected to the elearning teaching system; cadets and teachers database; list of courses; a list of the attendance of cadets and teachers; as well as provisions and regulations governing the use of e-learning teaching systems.

Whereas the process includes the implementation of e-learning through online teaching, presenting material with various models and varied teaching methods. In addition, both main and additional material can be accessed through an application that contains the whole process. The need for communication and interaction between cadets and teachers is also provided in a menu in the e-learning management process of the teaching system. Zhao J's research (2009) states that higher education students in China are still trying to adapt to the concept of independent learning management besides the inherent culture and history of lecturing methods with lectures which are still considered as the only effective way to convey material besides technology infrastructure is also still considered. less compared to western countries, however, several universities in China will follow this change which will apply the face-to-face concept in providing theoretical material followed by assignments and quizzes using the e-learning platform VLE's (virtual Learning environments) because it supports the combined concept of both face-to-face and e-learning as a new interactive learning experience.

The output contains the results of the teaching evaluation. The information contained in the e-learning management of the teaching system through the input process output, makes it easier for users to carry out the teaching process. The design of the e-learning management model for the Akpol teaching system that was developed is described through a learning management system (LMS) application which can also be accessed via the websites that can use the entire internet network. As for the design of this model, the implementation of the teaching process uses various methods and more varied teaching models by utilizing the use of ICT, a control 
system for teaching implementation by filling in validated attendance into the system, and loading the final assessment display as the output of this education management information system.

The characteristics of the e-learning management model of this teaching system contain criteria based on the TAM theory, consist of indicators such as flexible; effective; efficient; helpful; easy; continued use; attitude. To get a user account, there is an LMS, this teaching system, cadets and teachers, must register first which is then accepted by the operator to be verified first. If the user has received approval from the operator, they can then start using the e-learning. At this development stage, focus group discussions of FGD I and II were carried out with a revised model on the display feature and the discussion feature in the discussion process.

The results of consultations through experts in FGD II on the hypothetical model received some input in order to refine the model in order to get a final model that was suitable for use at the Police Academy. The inputs are: the model manual for improvement; use of this model so that later when it is applied it is always updated according to the conditions of the times; add features to the implementation of synchronous and asynchronous discussion forums and PBM reviews through the application; while the output is added to the cumulative score in of evaluation.

Then based on the final consultation, the responses obtained respond that the e-learning management model of the teaching system is suitable for use. Through the addition of previous suggestions, the model is further refined into the final model of e-learning management model for teaching systems in Police Academy. This final model is still packaged through an IPO education management information system (input-processoutput) framework. In the input stage, it includes all the initial information required in the planning stage that will be used by cadets before the process, availability of supporting tools as media; strengthening ICT skills; course data teaching and scheduling; cadets and teachers data; RPS learning documents; materials and additional materials in the form of e-books; e-learning regulations and operational guidance.

The process stage includes the implementation of the e-learning teaching system itself which includes: the use of an interactive teaching model; the use of varied teaching methods; utilization of the use of ICT through several webs; project-based assignments via the ÉLISA application; Providing quizzes in the application; portfolio as an integrated teaching review through the application; mentoring and guidance through synchronous asynchronous discussion forums. This is in accordance with the opinion of Cheng, F.F., et al. (2017) In using a web-based learning system asynchronously between system designers and educators, it is necessary to understand the influence between learning styles, materials and teaching methods on the effectiveness of the system..

The output stage is the stage of teaching results carried out through e-learning which includes the percentage of attendance of cadets and students who are validated and integrated through the application; selfassessment through an evaluation system in the form of a recording of the process implementation so that it can monitor material achievement; presentation of value in the ÉLISA app, and the complaint service portal. The elearning management development model of this teaching system has advantages and novelty, especially in combining all teaching components that are entered into an information system through the ÉLISA application which contains input-process-output that can be used in teaching.

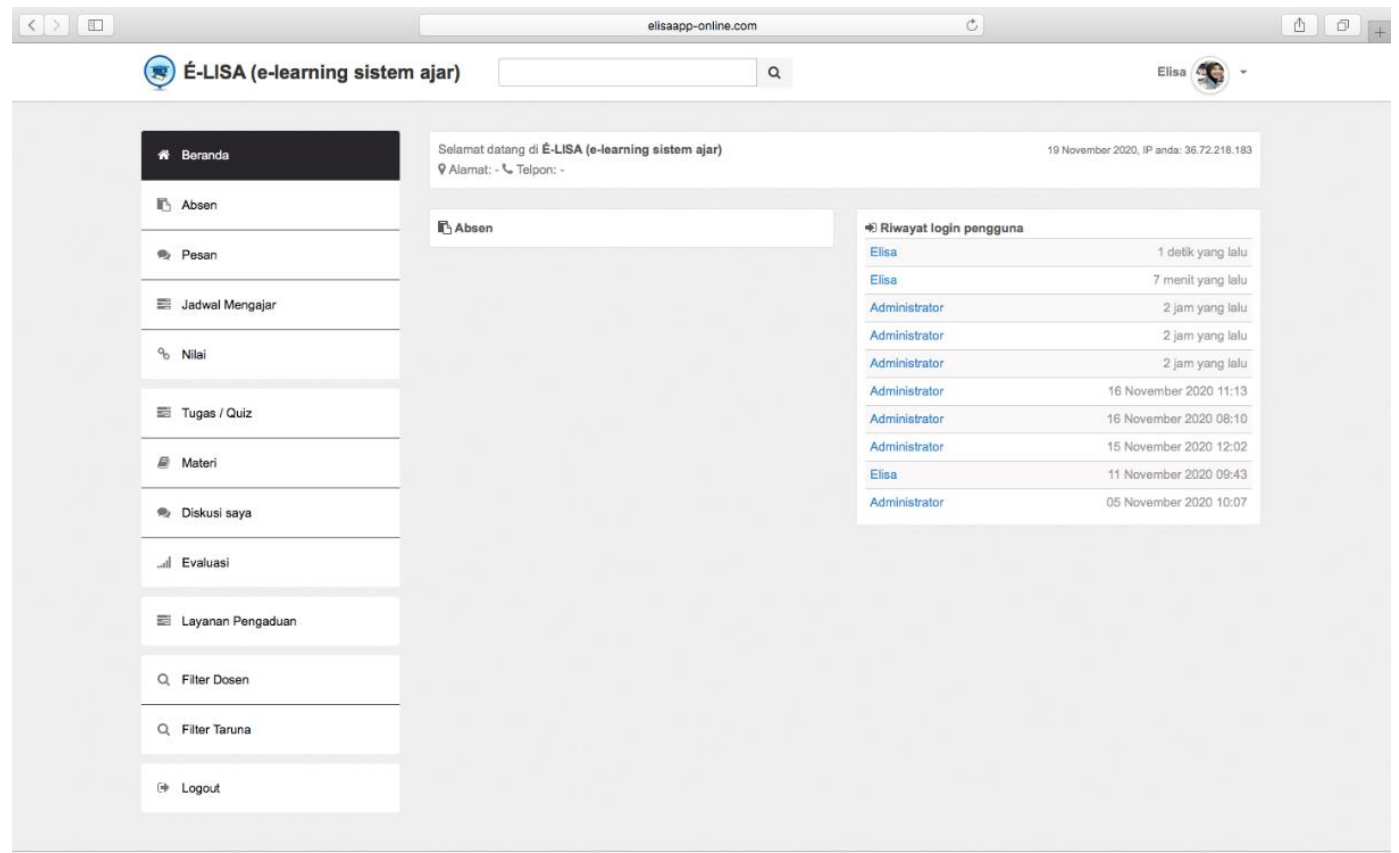

Figure 1. Final model management model using application ÉLISA 
As visualized in the figure, this is the final result after making all improvements to some of the features contained in the e-learning management model of the ÉLISA teaching system. The e-learning management model through the ÉLISA application has many differences compared to the e-learning that existed previously at Akpol. This application contains all the information needed by all users, especially cadets in supporting the teaching process held at the Police Academy. This e-learning model can also be implemented by combining faceto-face and online classes through the blended learning flipped classroom model so that this model can be used as a complement and support for teaching.

The results of the final model based on the final revision as a product improvement contain the entire elearning management teaching system through input-process-output. There is a slight change in the part of the process where the use of technology is maximized in the form of assignments, quizzes, and other project-based assignments that are presented in the e-learning application menu of the ÉLISA teaching system. There is also an interactive discussion forum between girls and cadets to answer additional questions asked by cadet. In the output system management contains all evaluation of teaching results which are presented into a folder that can be downloaded by the user. The supervisory function is also included in the education management information system at the output, namely the cumulative attendance system of cadets, which is also validated by the system, teaching evaluation and assessment, and complaint services. In addition, there is also a manual that can be used by users in operating this application.

Before the implementation of data collection, the instrument validity and reliability were tested. Based on the results of the SPSS 2.0 analysis, the scale corrected Item-Total Correlation value is described, the value that appears is the item validity value. While the Cronbach's Alpha if Item Deleted value is the Item Reliability value. To assess whether the above values (Item validity and Item reliability) are valid and reliable, $\mathrm{R}$ Table on DF $=\mathrm{N}$ $2(\mathrm{DF}=$ Number of samples -2$)$ and probability $0.05=\mathrm{DF}=100-2=98$. R table on DF 18 the probability of 0.05 is 0.1654 . So that the conclusion drawn based on these results is that the validity of the input, process and output instrument data is declared valid because the value of the corrected Item - total correlation>0.1654. In reliability statistics, seen from the value of Cronbach's Alpha Based on Standardized Items, this value is $>\mathrm{R}$ table 0.1654 which means that instrument items 1-30 are overall reliable. The results of the feasibility test of the model through FGD can be seen from each indicator of the TAM theory by Davis (1985) which includes 5 aspects, namely perceived ease of use (PEU); perceived usefulness (PU); Attitude towards using (ATU); Behavioral intention (BI); System Actual Usage (SAU). The results of the percentage feasibility of the e-learning model by experts and practitioners were that PEU was 93.7\%, PU was 97.5\%; ATU of 93.7\%; BI at 92.5\%; SAU at $100 \%$. The results of the feasibility of the e-learning management model are seen in the input-process-output education management information system of each management indicator which includes 3 aspects, namely input-process-output. The result of the feasibility of the percentage of the e-learning management model is that the input is $95 \%$, the process is $95.8 \%$, and the output is $95 \%$.

After revision to the previous model based on the hypothetical model, then a limited trial was carried out for the development of an e-learning management model for the teaching system using the ÉLISA application using the pre and post test. Based on the research results of the e-learning management model for the teaching system developed, the following results were obtained:

\begin{tabular}{llllll}
\hline \multicolumn{7}{c}{ Descriptive Statistics } & \multicolumn{5}{c}{ Maximu } \\
& N & Minimum & m & Mean & Std. Deviation \\
\hline Pree Test & 100 & 38.00 & 89.00 & 64.6000 & 7.56787 \\
\hline Post Test & 100 & 88.00 & 149.00 & 135.6000 & 10.62016 \\
\hline $\begin{array}{c}\text { Valid } \\
\text { (listwise) }\end{array}$ & N & \multirow{2}{*}{100} & & & \\
\hline
\end{tabular}

Source: Primary Data Processed, 2020

Tabel 1.Description of Pre Test and Post Test Results for the E-Learning Management Model of the teaching system

Based on Table 1 above, it can be explained that the pre-test score before e-learning management is applied according to its use and correct procedures with management functions starting from input to processing, the mean is 64.6000 with a standard deviation of 7.56787. Meanwhile, the post-test results after e-learning management was applied in learning obtained a mean of 135.6000 with a standard deviation of 10.62016. These results can be explained that the application of the teaching system management model that has been developed can increase the optimal use of e-learning in Police Academy. The following is a description of the pre-post test for the acquisition of a teaching system e-learning management score: 


\begin{tabular}{clll}
\hline No. & Score range & PreTest & Post Test \\
\hline 1 & & 7 & 0 \\
\hline 2 & $31-55$ & 92 & 0 \\
\hline 3 & $56-80$ & 1 & 1 \\
\hline 4 & $81-105$ & 0 & 18 \\
\hline 5 & $106-130$ & 0 & 81 \\
\hline & $131-155$ & 100 & 100 \\
\hline & Jumlah & $\mathbf{3 8}$ & $\mathbf{1 0 5}$ \\
\hline & Min & $\mathbf{8 9}$ & $\mathbf{1 4 9}$ \\
\hline
\end{tabular}

Source: Primary Data Processed, 2020

Tabel 2.Result of pre and postModel

Based on Table 2 above, it can be explained that the pre-test conditions for the use of e-learning teaching systems do not have a maximum score related to the use of e-learning teaching systems, including downloading RPS, following learning with applications, making project assignments with e-learning applications and obtaining the mean pre test was 64,6000 which is far away when compared to the post test results. While the mean post test acquisition was 135.6000 , thus there was an increase in the score of 71 scores or $47.33 \%$. The results of descriptive analysis related to the results of the pre test and post test are presented in the form of a graph or bar chart as shown in Figure 2 below.

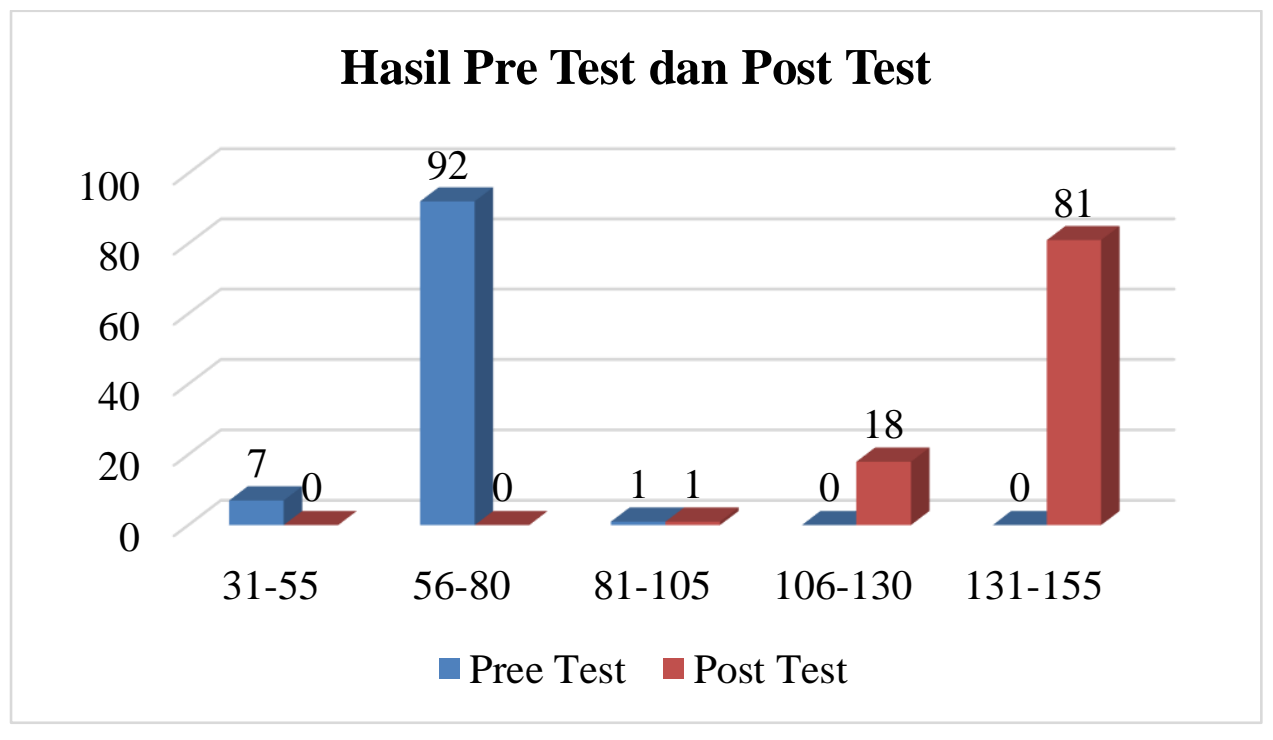

Figure 2.Description pre \&post test the use of e-learning management

Based on Figure 2 above, it can be explained that before the use of e-learning management, the teaching system of Akpol, the most scores were obtained at 56-80 intervals as much as $92 \%$ in the fairly good category. Meanwhile, after the use of e-learning management, the teaching system for Akpol, the most scores were obtained at the $131-155$ interval as much as $81 \%$ in the very good category.

\section{Paired Samples Statistics}

\begin{tabular}{|ll|l|l|l|l|}
\hline & & Mean & $\mathrm{N}$ & Std. Deviation & Std. Error Mean \\
\hline Pair 1 & Post Test & 135.6000 & 100 & 10.62016 & 1.06202 \\
& Pree Test & 64.6000 & 100 & 7.56787 & .75679 \\
\hline
\end{tabular}

Source: Primary Data Processed, 2020 
Tabel 3.Paired Statistik Pre Test dan Post Testthe use of e-learning management

\section{Paired Samples Correlations}

\begin{tabular}{llllc}
\hline & N & Correlation & Sig. \\
\hline Pair 1 & Post Test \&Pree Test & 100 & .602 & .000 \\
\hline
\end{tabular}

Source: Primary Data Processed, 2020

Tabel 4 correlation analysis pre-post testthe use of e-learning management model

Based on Table 4 above, it can be explained that the e-learning management model of the teaching system used at the Police Academy for research is good, this result is indicated by a correlation coefficient of 0.602. This is shown in the pre-test results before using the e-learning management model of the teaching system and after the application of the e-learning management model the teaching system has a positive and significant correlation. With a computer output of 0.000 which is smaller than alpha 0.05 . These results indicate that the elearning management model of the teaching system at the Police Academy is good and effective with a positive and significant correlation. A positive sign can also be interpreted if the application of e-learning management of the teaching system is getting better, the learning outcomes with the application system will also increase.

The calculation of the Gain index is used to determine the level of effectiveness of a treatment on the expected results in this study is the e-learning management model of the teaching system in Police Academy. The criteria used to interpret the value of Gain are: Gain $\geq 0.7$ means high; $0.3 \leq 0.7$ means moderate; and Gain $<0.3$ means low (Hake, 1999: 1; Melzer in Sulistiyono, 20014). Based on the results of the pretest, it was found that the average value of the e-learning management model for the teaching system was 61.60, while the post-test results of the application of the e-learning management model for the teaching system obtained a value of 135.60. Thus, it can be seen that there is an increase in the application of the e-learning management model of the teaching system from before the model is applied and after the model is applied. To determine the level of effectiveness of the model that has been applied in this study, it can be calculated using the Gain Index above, which is as follows:

$$
\begin{aligned}
\text { Indeks Gain }=\frac{(135,60-64,60)}{(150-84,60)} \\
\text { Indeks Gain }=\frac{(71)}{(85,4)} \\
\text { Indeks Gain }=\mathbf{0 , 8 3 1}
\end{aligned}
$$

Based on the Gain index criteria table $(G)$, the effectiveness of the e-learning management model for the teaching system applied at the Police Academy is in the range of Gain values $\geq 0.7$; it means that the value of the Gain index is 0.831 in the medium category (high-G). Therefore the results of the above calculations indicate that the e-learning management model of the teaching system that was developed is effectively used in the Police Academy with a high level of effectiveness (high-G). Testing the effectiveness of the model then used the -t test and the average increase of the pre test and post test in the e-learning teaching system.

To determine the level of effectiveness of the model used in this study, a parametric statistical test was

\begin{tabular}{|c|c|c|c|c|c|c|}
\hline \multicolumn{7}{|c|}{ Paired Samples Test } \\
\hline \multicolumn{4}{|c|}{ Paired Differences } & \multirow{3}{*}{$\mathrm{t}$} & \multirow{3}{*}{ df } & \multirow{3}{*}{$\begin{array}{l}\text { Sig. } \\
\text { tailed })\end{array}$} \\
\hline \multirow[t]{2}{*}{ Mean } & \multirow[t]{2}{*}{$\begin{array}{c}\text { Std. } \\
\text { Deviation }\end{array}$} & \multirow[t]{2}{*}{$\begin{array}{l}\text { Std. } \\
\text { Mean }\end{array}$} & $\begin{array}{l}\text { 95\% Confidence Interval of } \\
\text { the Difference }\end{array}$ & & & \\
\hline & & & \begin{tabular}{|l|l} 
Lower &
\end{tabular} & & & \\
\hline
\end{tabular}
performed using the t-test. The -t test results on the pretest and posttest results of the e-learning management model for the teaching system using SPSS version 24 from IBM, obtained the following analysis results: 


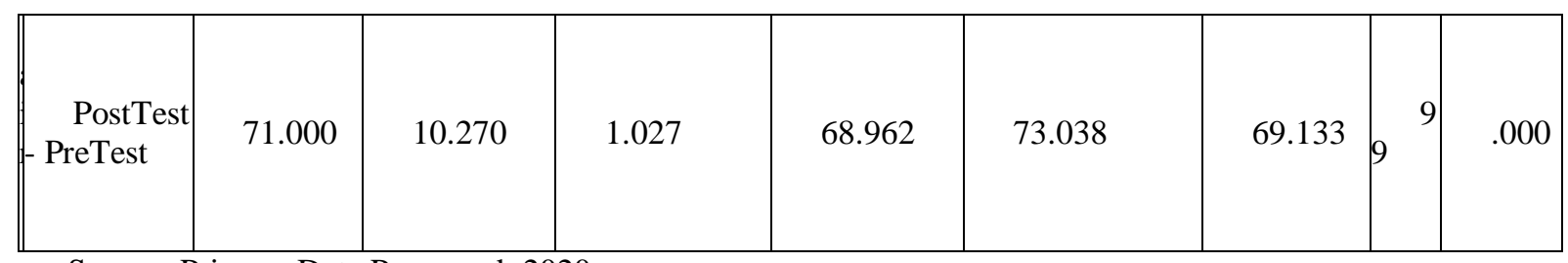

Source: Primary Data Processed, 2020

Tabel5the result of t-test implementation of e-learning model

The results of the data analysis show that the $t$ value for the statistical test is 69.133 with a significant level of Sig $=0.000(\mathrm{p}<0.05)$, which means that there is a difference between the average pretest score and the post-test score is accepted. It can be concluded that "Ha is accepted". This means that there is a difference between the results of the e-learning management model for the pretest and posttest, so it is also concluded that the effectiveness of the e-learning management model for learning systems at the Indonesian Police Academy. Based on the conclusion of the statistical test results above, the e-learning management model of the ÉLISA teaching system is effective as an e-learning model for a teaching system that is useful and useful so that it can be applied in the Police Academy..

In summary, this effectiveness test can be shown, as follows:

1. The mean post test score was higher than pre test, meaning a increase of $47,33 \%$.

2. The pre-test and post-test correlation coefficient of 0,602 means that there is a correlation and significance of the results with Sig. $000<0,05$

3. The $\mathrm{N}$-Gain result is 0,831 in the high category, meaning that the application of the e-learning application system model is good and effective to improve learning.

4. The t-test result shows that $\mathrm{t}$ for the statistical test is 69,133 with a significant level of Sig. $=0,000$ (p $<$ $0,05)$ which means that the model is effective.

5.

The use of the ÉLISA application can also provide benefits for organizational effectiveness in carrying out the educational process. Based on the results of the SPSS analysis test, the results of data analysis showed that the $t$ value for the statistical test was 69.133 with a significant level of Sig $=0.000(p<0.05)$, which means that there was a difference between the average pretest score and the post-test score was accepted. It can be concluded that "Ha is accepted". This means that there is a difference between the results of the e-learning management model for the pretest and posttest, so that it is also concluded that there is the effectiveness of the elearning management model for teaching systems for learning at the Police Academy. Based on the conclusion of the statistical test results above, the e-learning management model of the ÉLISA teaching system is effective as an e-learning model for a teaching system that is useful and useful so that it can be applied in Police Academy.

This is in line with the findings of El-Bakry, H.M \& Mastorakis. (2007) which states that the use of elearning is a learning revolution using the latest technology so as to produce effective and efficient learning. The same thing was also stated in Rui-Hsin \& Lin's previous research (2017) that the use of e-learning for education and training in the Taiwan Police had a positive impact on the educational process, especially in its ease of use and an increase in service quality which had an impact on the speed of obtaining information through the use of the web, besides that it can also encourage the learning independence of students and increase the ability of human resources in operating a technology in the police education and training information system.

\section{CONCLUSION}

This research and development has resulted in an e-learning management model for the AKPOL teaching system through an ÉLISA application which can be applied as the use of ICT in the application of elearning by using input-process-output management. This model has quite high effectiveness seen in education management and the concept of TAM theory based on aspects of ease, usability, user attitudes, sustainability, user interest in application use.

\section{REFERENCES}

1. Berge, Z. \& Huang, Y.P. (2004). A Model For Sustainable Student Retention: A Holistic Perspective On The Student Dropout Problem With Special Attention To E-Learning”. Deosnews, Vol. 13 No. 55, pp.1-26.

2. Borg, Walter R. dan Gall, M, Damien. 2013. Educational Research: An Introduction, Fifth Edition. New York: Longman. 
3. Cheng,F.,Chieu,C.,Wu,C.S.,\&Tsaih,D.C. (2017). The Influence Of Learning Style On Satisfaction And Learning Effectiveness In The Asynchronous Web-Based Learning System. Emerald publishing: Vol.35, no.4.

4. Davis, F.D. (1993). Perceived usefulness, perceived ease of use, and user acceptance of information technology. MIS Quarterly, Vol.13, No.3., pp.319-340.

5. El-Bakry,H.M. \&Mastorakis,N. (2009). E-Learning And Management Information System For EUniversities. Proceedings of the $13^{\text {th }}$ WSEAS International Conference.

6. Kettunen,J.,\&Kantola,I. (2005). Management Information System based on the balanced scorecard. Emerald: vol 22.no 5,2005.

7. Khristianto,W.,Supriyanto,T.,\&Wahyuni,S. (2015). SistemInformasMAnajemen: PendekatanSosioteknik.UPT UNEJ

8. Leal, J. (2009). E-Learning And Online Edication: Implications For The Future Of Law Enforcement Training. Sagepub.

9. McMahon,W.W. (2003) TerjemahanNunikNurjannah. Jakarta : Abas Al Jauhari.

10. Meltzer, D.E. 2002. The Relationship Between Mathematics Preparatioan and Conceptual Learning Gains In Physics: A Possible "Hidden Variable" In Diagnostic Pretest Scores. Departement Of Physics and Astronomy, Lowa State University. Vol 70, No 12 December 2002

11. Rosenberg, M.J. (2001). E-Learning: Building successful Onine learning in Your Organization. McGraw-Hill

12. Rui-Hsin,K.\& Lin Chen-Tai. (2017). The Usage Intention of e-learning for Police Education and Training. Policing: An International Journal Vol.41 No.I, 2018 pp.98-112: Emerald Publishing Limited.

13. Sagitova,.K. (2012). Management Information System for Higher Educational Institutions During Kazakhstan Transition to Knowledge Economy. World Applied Science Journal 18.

14. Shah, M. (2013). Impact Of Management Information Systems(MIS) On School Administration: What The Literature Says. Elsevier.

15. Vioren., Oktaria, D., \& Hamidi, S. (2019). MetodePembelajaran Flipped Classroom dalam Pendidikan Kedokteran. Medula: vol.8 no.2.

16. Zhao, J. (2009). Teachers; Conceptions of E-Learning In Chinesehigher Education: A Phenomenographic Analysis. Emerald insights:Vol.26 No.2.2009. 